\title{
Economic-statistical Evaluation of Sustainable Development of Forest Trees
}

\author{
Marcela Malindzakova ${ }^{1}$, Dusan Malindzak, jr. ${ }^{2}$, Patrik Garaj ${ }^{1}$ \\ ${ }^{1}$ Technical University of Kosice, Institute of Logistics and Transport, Park Komenskeho 14, Kosice, Slovakia \\ ${ }^{2}$ U. S. Steel Kosice, Vstupny areal U. S. Steel Kosice, Slovakia
}

\begin{abstract}
The paper deals with the application of individual simple and second generation indexes Laspeyres price index (Ip), Laspeyres volume index (Iq). The individual statistical indexes compare parameters, namely the volume of harvested trees and the economic evaluation of forest management for the time periods 2015-2016, 2016-2017 and 2017-2018. Economic-statistical indexes are applied for economic evaluation of forest management. The subject of the paper is to demonstrate how the implementation of the Laspeyres price index (Ip), of the Laspeyres volume index (Iq) can help with forest management to obtain clear statistics on logging and the need to replace the original stand.
\end{abstract}

Keywords - Forest management, sustainability, economic-statistical evaluation, ecology

\section{Introduction}

Sustainable forest management (SFM) must ensure appropriate environmental, social but also economically viable conditions for the future development. Therefore, the requirements of sustainable forest management should always be adapted to the new requirements and must take into account the specific environmental and ecological conditions as well as the political, economic, spiritual and cultural dimensions [1].

DOI: $10.18421 /$ TEM103-40

https://doi.org/10.18421/TEM103-40

Corresponding author: Marcela Malindzakova,

Technical University of Kosice, Slovakia.

Email: marcela.malindzakova@tuke.sk

Received: 02 June 2021.

Revised: 28 July 2021.

Accepted: 04 August 2021.

Published: 27 August 2021.

(c) Br-NC-ND (C) 2021 Marcela Malindzakova, Dusan Malindzak \& Patrik Garaj; published by UIKTEN. This work is licensed under the Creative Commons AttributionNonCommercial-NoDerivs 4.0 License.

The article is published with Open Access at www.temjournal.com
The definition of sustainable forest management contained in the Resolution adopted at the Ministerial Conference on Forest Protection in Europe in Helsinki in 1993 is shared by both the Slovak system and the Program for the Endorsement of Forest Certification Schemes (PEFC). The SFM is defined as follows:

Sustainable forest management means the use and management of forests, but also of forest land to such an extent that it maintains its ability to restore, productivity, vitality and its potential now and in the future. It is recommended to consider using larger areas to achieve better options for forest management and its optimization in order to properly balance often the conflicting goals, namely the timber harvest whilst at the same time to strive for biodiversity conservation. Increasing the forest management areas can improve to certain degree the planning optimization in regard to both objectives [1]. The SFM supports the most important economic, environmental and social functions at regional, but also national and global levels, without having a negative impact on the remaining ecosystems [2].

The research in the area of sustainable forest management went through three distinct phases. The topic came into prominence with the general treatment of tropical forests in the developing countries. The second phase followed with issues such as forest management, certification and the sustainability indicators development. More recently the third phase aimed attention on the climate change issues [3].

\section{European Criteria for Sustainable Forest Management}

Recent findings indicate that the growing Human Development Index as defined by the United Nations Development Programme (UNDP) correlates positively with grow of forest resources in the given country. This indicates that with growing wellbeing of people in given country the forest resources also improve. As it was observed, the more developed countries apply modern renewal methods on quality farmlands and leave marginal lands for forest 
expansions. Furthermore, better developed countries invest into sustainable forest management programs and nature protection [4].

This factor contributed to a considerable shift in the perception of forests utilization from timber production as a sole objective to a sustainable forest management. This gradual shift has been caused by the changes in people's attitudes towards forests. This has been subsequently implemented into national regulations and policies, as well as European and global policy changes. Therefore, currently, the policy makers are concerned with issues of sustainability and multifunctional land use, through safeguarding and protecting the natural environment [5]. Through European standards and standards that serve to evaluate and categorize forests, the forest management can be addressed in accordance with sustainable forest management practices, the fulfilment of which is an essential part for issuing a certificate. Forestry companies must comply with the six basic European criteria for sustainable management [6]:

1. Criterion - Maintain and adequately develop forest resources and their contribution to the global carbon cycle. The aim of this criterion is to focus on general preparedness, land area and land use and carbon balance.

2. Criterion - Maintain vitality and health of forest ecosystems. This criterion concerns the management of the ecosystem.

3. Criterion - Maintain and promote productive forest functions (wood and non-wood products). This criterion is aimed at forest production.

4. Criterion - Maintain and adequately develop and protect the diversity of ecosystems in the forest. This area focuses on general conditions, rare and easily vulnerable forest ecosystems, endangered species and biodiversity in farm forests.

5. Criterion - Preserve and develop forest conservation evenly. This area focuses on general protection, soil erosion and water conservation in forests.

6. Criterion - Maintain other economic and social functions and requirements. The priority of this criterion is to focus on the importance of the forest sector, the provision of work, training and research, public awareness and cultural values.

In the forest tree gene pool, the protection, reproduction and management of their resources are also associated with the provision and application of forest reproductive material. Pursuant to Act No. 138/2010 Coll. the genetic resources of trees are provided for the objectives of conservation and sustainable use of biodiversity in approved gene bases, resources, forest seed and forest tree seed banks [2].
The material flow of sustainable forest management consists of five basic activities as follows [7]:

1. Technological activities - are operations through which the forest cover is maintained, protected and processed.

2. Quality activities - The quality of activities and the quantity of materials delivered and processed shall be checked.

3. Transport activities - represent the rationalized movement of material in different directions, or the transfer of work items. For example, lifting, lowering, turning, transfer between workplaces in the company, and so on.

4. Storage - The aim is to keep the work item in the warehouse, at the input, in the interim production warehouses as well as other storage.

5. Delay - is any unplanned postponement of the work item associated with waiting time for the next material flow activity.

Control and technological activities are connected with the creation and processing of forest foliage, delay and storage are connected with the storage of material and transport activities are connected with movement. All non-technological, material flow activities are together commonly referred to as material handling (transport, storage, delay and control) [8].

In regard to the actual forest management planning within the investigated company, it is recommended to plant forests early in the spring, due to the soil moisture after winter. On the other hand, the planting of seedlings in the early spring may slow down the development of the seedlings, which might be caused by cold weather. As a priority, larch and then all deciduous trees are planted. Conifers are planted last. Spring afforestation is best suited to afforestation of open-rooted seedlings. At present, a major problem is caused by climatically uneven years, extreme temperatures as well as by the drought in April. It is up to the forest manager to decide whether to perform afforestation also in the autumn. Openrooted coniferous trees can be planted as early as September. In case of favourable weather, it is possible to plant broad-leaved deciduous trees and larch after fall. It can also be planted in autumn months, namely in October and November. The planting of broad-leaved deciduous and coniferous seedlings is relatively risky during the summer months due to the lower occurrence of rainfall, and later also due to the occurrence of frost [2].

\section{Materials and Methods}

Forest Stewardship Council (FSC) is an international and non-profit organization. The role of the organization is to conduct interviews as well as 
assess forestry and solve the world's environmental problems, but also in terms of economic forest management. In Slovakia, the aims and ideas of the FSC are promoted through a non-governmental civic association.

The FSC certification system is divided into three parts [9]:

1. Accreditation within a given time frame shall be the audited operations of accredited certification bodies. The International FSC only certifies companies that are trusted and trusted with goodwill.

2. Standardization creation of the FSC standards, norm and criteria worldwide.

3. Certification is oriented to assessing the quality of forest management through specified procedures. A third-party inspection is carried out to assess forest management.

The focus of the investigated company is the management of forest and other properties owned by the Slovak Republic. The investigated company has the right to conduct business with continuous operational production and trade. The aim of the enterprise is to meet the needs of the forest, the public and the environment as well as to make a reasonable profit through the use of sustainable development.

With the help of a long-term design, they are responsible for maintaining and reproducing the gene pool of forest trees. Through this proposal for the protection of the forest gene pool, the following two parts are defined [10]:

1. Nationwide - pursuing natural forest regeneration, through selective and controlled seedlings as well as the creation of artificial regeneration.

2. Area Specific - provision and management of genetic resources where they are predominantly located, namely:

- approved parts of the forest for seed collection,

- genetic bases,

- trees that have been selected,

- seed orchards and stands,

- gene parts of forest trees.
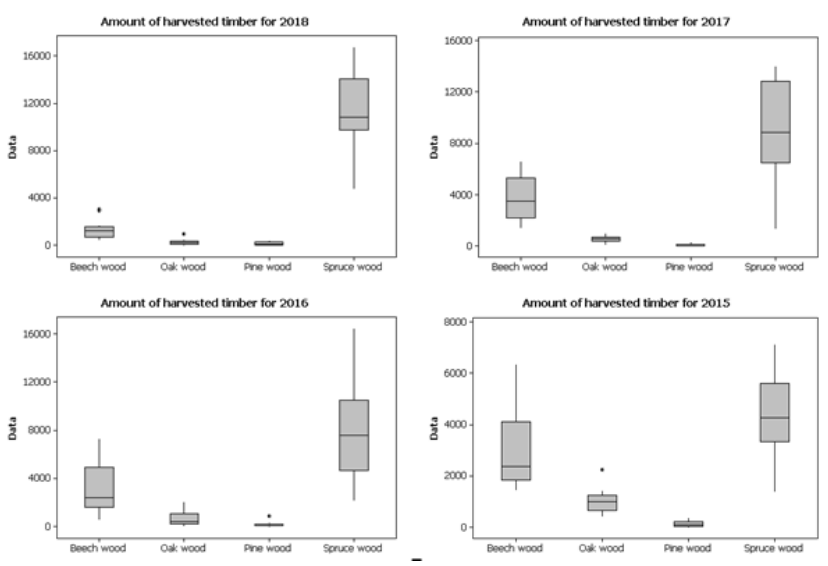

Figure 1. The amount of harvested timber for the period $2015-2018$

Although in the territory of the Eastern Slovakia region a suitable, assimilated and genetically valuable tree populations have been preserved, the gene pool must be protected. There are various factors negatively influencing tree genepool, such as pollution from agriculture and air, climate differences, forest fragmentation, abiotic and biotic harmful factors, as well as inappropriate management decisions [10].

Figure 1. shows the most harvested timber types, namely beech and spruce that were harvested in 2014-2017. Only in limited quantities pine wood was harvested. Growing spruce logging has been associated with the crustacean calamity between 2015 - 2018. For this reason, the economic evaluation of forest management needs to be addressed. Economic-statistical indexes can be applied for this purpose.

\section{Individual Statistical Indexes}

In this article two types of quantities will be compared, namely the intensive and extensive quantities. For intensive quantities $\mathrm{p}$ [11]:

$$
I_{p}=\frac{p_{1}}{p_{0}}
$$

and extensive $\mathrm{q}$ and $\mathrm{Q}$ have the form [6]

$$
I_{q}=\frac{q_{1}}{q_{0}}, I_{Q}=\frac{Q_{1}}{Q_{0}}
$$

and for comparison, which is absolute, it is possible to calculate the investigated quantities as corresponding absolute differences [11]:

$$
\Delta q=q_{1}-q_{0}, \Delta Q=Q_{1}-Q_{0}, \Delta p=p_{1}-p_{0}
$$


Extensive quantities describe the quantitative range of the quantity, e.g., volume, quantity, weight, range, etc. The values of extensive quantities can be obtained by direct measurement.

Intensive variables explain the intensity of the phenomenon in relation to another phenomenon. Intensive variables express the ratio of two extents (e.g., price of harvested wood mass).

\section{Second Generation Indexes}

Second generation indexes respect the volume and price of products and thus better reflect reality. These indexes have the form of the first level weighted characteristics. The most commonly used indexes with widespread implementation within this generation are [11]:

Laspeyres price index:

$$
I_{p}^{L}=\frac{\sum p_{1} \cdot q_{0}}{\sum p_{0} \cdot q_{0}}
$$

Laspeyres price index compares the value of production, measured at current period prices from base period prices, with the value of the same production as shown at base period prices. It shows production growth due to price changes with unchanged quantities of products [11].

Laspeyres volume index:

$$
I_{q}^{L}=\frac{\sum q_{1} \cdot p_{0}}{\sum p_{0} \cdot q_{0}}
$$

Laspeyres volume index seeks to compare the production values of the current period with the value of the same production at the prices of the base period, such as it provides information on the increase in production value due to price changes, but only if the produced quantity is withdrawing from the current period [11].

Both indexes are also important in that their values define the time interval in which the values of other indexes are found. They do not pass the time-change test, they are not suitable for creating chain and base indexes.

The boundaries of the interval consist of these two indexes, in which the values of the other indexes are. Thanks to good economic interpretation they are widespread in practice. They are dependent on the selection of weights and do not pass the test of confusion with time. They are used mainly when there are no huge variations in the composition of the value for the current and base periods.

$$
\text { Absolute differences }(L) \Delta L=\sum p_{1} q_{0}-\sum p_{0} q_{0}
$$

correspond to the above indexes which represent a cost increase (if positive) or even a cost saving (if negative) resulting from a decrease or increase in the prices of base period products.

The FSC certificate (Forest Stewardship Council) is awarded on the basis of the certification report that is the output of the audit. The FSC trademark signifies that the wood used to make the product is from forests that are harvested responsibly and well managed according to strict environmental, social and economic standards. For a person who buys a product, the FSC label is a guarantee that he buys a product that does not contribute to the destruction and damage of forest ecosystems and prevents illegal logging in the forest [12].

\section{Discussion}

Using simple and second-generation indexes - the Laspeyres price index $\left(I_{p}^{L}\right)$, the Laspeyres volume index $\left(I_{q}^{L}\right)$, the parameters for 2015-2016, 20162017 and 2017-2018 were compared which showed the differences in prices and volume of the harvesting rates for the monitored tree species.

\begin{tabular}{|c|c|c|c|c|c|c|}
\hline \multirow{2}{*}{$\begin{array}{l}\text { Type of } \\
\text { wood }\end{array}$} & \multicolumn{2}{|c|}{$\begin{array}{c}\text { Price of } \\
\text { wood [Eur] }\end{array}$} & \multicolumn{2}{|c|}{$\begin{array}{l}\text { Quantity of } \\
\text { wood }\left[\mathrm{m}^{3}\right]\end{array}$} & \multicolumn{2}{|c|}{$\begin{array}{l}\text { Revenue } \\
{\left[10^{3} \text { Eur }\right]}\end{array}$} \\
\hline & $\mathrm{p}_{0}$ & $\mathrm{p}_{1}$ & $\mathrm{q}_{0}$ & $\mathrm{q}_{1}$ & & $\mathrm{Q}_{1}$ \\
\hline Beech & 43.2 & 44.7 & 3185 & 3736.6 & 137.5 & 167.0 \\
\hline Oak & 54.9 & 55.2 & 689 & 568.9 & 37.8 & 31.4 \\
\hline Pine & 35.5 & 36.0 & 175 & 101.4 & 6.2 & 3.6 \\
\hline $\begin{array}{l}\text { Common } \\
\text { spruce }\end{array}$ & 49.3 & 46.8 & 7917 & 0 & 390. & 128.4 \\
\hline
\end{tabular}

Table 1. Calculation of price, quantity and sales focused on harvesting of monitored tree species for 2015, 2016

\begin{tabular}{|c|c|c|c|c|c|c|}
\hline $\begin{array}{l}\text { Type of } \\
\text { wood }\end{array}$ & \multicolumn{2}{|c|}{$\begin{array}{c}\text { Price of } \\
\text { wood [Eur] }\end{array}$} & \multicolumn{2}{|c|}{$\begin{array}{l}\text { Quantity of } \\
\text { wood }\left[\mathrm{m}^{3}\right]\end{array}$} & \multicolumn{2}{|c|}{$\begin{array}{l}\text { Revenue } \\
{\left[10^{3} \text { Eur }\right]}\end{array}$} \\
\hline & $\mathrm{p}_{0}$ & $\mathrm{p}_{1}$ & $\mathrm{q}_{0}$ & $\mathrm{q}_{1}$ & $\mathrm{Q}_{0}$ & $\mathrm{Q}_{1}$ \\
\hline Beech & 44.7 & 47.9 & 3736 & 1323.5 & 167.0 & 63.4 \\
\hline Oak & 55.2 & 66.3 & 569 & 252.8 & 31.4 & 16.7 \\
\hline Pine & 36.0 & 31.4 & 101 & 125.3 & 3.7 & 3.9 \\
\hline $\begin{array}{l}\text { Common } \\
\text { spruce }\end{array}$ & 46.8 & 46.4 & 9155 & 11571 & 428.4 & 536.7 \\
\hline
\end{tabular}

Table 2. Calculation of price, quantity and sales focused on harvesting of monitored tree species for 2016, 2017

\begin{tabular}{|c|c|c|c|c|c|c|}
\hline $\begin{array}{l}\text { Type of } \\
\text { wood }\end{array}$ & $\begin{array}{r}\text { Pri } \\
\text { wooc }\end{array}$ & $\begin{array}{l}\text { of } \\
\text { [Eur] }\end{array}$ & $\begin{array}{l}\text { Qua } \\
\text { wo }\end{array}$ & $\begin{array}{l}\text { tity of } \\
d\left[\mathrm{~m}^{3}\right]\end{array}$ & & $\begin{array}{l}\text { enue } \\
\text { Eur] }\end{array}$ \\
\hline Beech & $\begin{array}{c}\mathrm{p}_{0} \\
47.9\end{array}$ & $\begin{array}{c}\mathrm{p}_{1} \\
54.8\end{array}$ & $\begin{array}{c}\mathrm{q}_{0} \\
1323\end{array}$ & $\begin{array}{c}\mathrm{q}_{1} \\
1067.3\end{array}$ & $\begin{array}{c}\mathrm{Q}_{0} \\
63.4\end{array}$ & $\begin{array}{c}\mathrm{Q}_{1} \\
58.5\end{array}$ \\
\hline Oak & 66.3 & 68.5 & 253 & 220.7 & 16.8 & 15.1 \\
\hline Pine & 31.4 & 31.2 & 125 & 84.2 & 3.9 & 2.6 \\
\hline $\begin{array}{c}\text { Common } \\
\text { spruce }\end{array}$ & 46.4 & 50.0 & 11571 & 10195 & 536.7 & 508.8 \\
\hline
\end{tabular}

Table 3. Calculation of price, quantity and sales focused on harvesting of monitored tree species for 2017, 2018 
From the implementation of simple individual indices of the Laspeyres price index $\left(I_{p}^{L}\right)$, the Laspeyres volume index $\left(I_{q}^{L}\right)$, it can be stated (Table. 1) that the price of beech wood in 2016 increased by $3.47 \%$ compared to the base period (2015). This increase is 1.5 Eur.m $^{3}$. Sales of European beech increased by $17.32 \%$ in 2016 , namely $551.50 \mathrm{~m}^{3}$ compared to the base year 2015 (Table 1.). In 2017, the price for beech increased by $7.18 \%$ compared to 2016 , namely by 3.21 Eur.m ${ }^{3}$. Significant decrease in sales of European beech trees can be seen (Table 2.) in 2017, it is a decrease of $64.58 \%$, specifically the amount represents $2413 \mathrm{~m}^{3}$. This decrease was caused by the shift of logging groups to calamity logging. Consequently, in 2018 the price for beech increased by $14.42 \%$, which represents an increase of 6.91 EUR.m. ${ }^{3}$. A further decline can be seen in 2018, where the volume of beech sales decreased by $19.4 \%$ compared to 2017 (Table 3.).

The results of simple individual indices show that the price of the winter oak tree in 2017 increased by $20.11 \%$ compared to the base period, i.e., 2015, which represents an increase of 11.1 Eur. $^{3}$ in financial terms (Table 2.). The volume of harvested winter oak has decreased by $55.56 \%$, which represents a reduction of $316.15 \mathrm{~m} 3$. In 2018 the price per $\mathrm{m}^{3}$ increased only slightly by $3.25 \%$, namely by 2.16 Eur.m $^{3}$. It is also possible to see (Table 3.) that the volume of harvested oak species decreased again by $12.7 \%$.

In the assortment of pine wood, the results of simple individual indices in 2016 show a price increase of $1.41 \%$ compared to the base period that is the year 2015. On the other hand, the volume of forest pine harvested decreased by $41.99 \%$, namely $73.4 \mathrm{~m}^{3}$. In 2017 the price per $\mathrm{m}^{3}$ decreased by $13.06 \%$, which represents a decrease of 4.7 Eur.m ${ }^{3}$. In 2018 , the price per $\mathrm{m}^{3}$ remained unchanged, but in terms of the amount of timber harvested, a decrease of $32.76 \%$ can be seen. The reason was the need to process the current pine calamity.

The values obtained through simple individual indices indicate that the price for the Norway spruce tree decreased slightly in 2016, namely by $5.07 \%$ compared to the baseline period, which is the year 2015. The volume of tree spruce harvested in 2016 increased by $15.64 \%$, which represents an increase of $1238 \mathrm{~m} 3$ (Table 1.). In 2017, the price per $\mathrm{m}^{3}$ of spruce wood increased only slightly, which is by $1.07 \%$, but on the other hand, there was a significant increase in the volume of tree spruce. The percentage represents an increase of $26.39 \%$, which translates to $2416.3 \mathrm{~m}^{3}$ (Table 2.). This increase was influenced by the following two factors [12]:
1. pest infestation, in particular spruce bark beetle,

2. wind calamity.

In 2018 , the price per $\mathrm{m}^{3}$ of spruce was increased only slightly by $7.59 \%$. Table 3 . presents a decrease in the volume of harvested tree spruce by $11.88 \%$, which represents a reduction of $1374.97 \mathrm{~m}^{3}$ (Table 3.).

Table 4. Aggregates indices for evaluation of harvesting of monitored tree species for 2015, 2016, 2017, 2018

\begin{tabular}{|ccccccc|}
\hline Type of & \multicolumn{2}{c}{ Years 2017, } & \multicolumn{2}{c|}{ Years 2016, } & \multicolumn{2}{c|}{ Years 2015, } \\
wood & \multicolumn{2}{c}{2018} & \multicolumn{2}{c|}{2017} & \multicolumn{2}{c|}{2016} \\
& $\mathrm{I}_{\mathrm{p}}$ & $\mathrm{I}_{\mathrm{q}}$ & $\mathrm{I}_{\mathrm{p}}$ & $\mathrm{I}_{\mathrm{q}}$ & $\mathrm{I}_{\mathrm{p}}$ & $\mathrm{I}_{\mathrm{q}}$ \\
Beech & 1.14 & 0.81 & 0.93 & 2.82 & 1.04 & 1.17 \\
Oak & 1.03 & 0.87 & 0.83 & 2.25 & 1.00 & 0.83 \\
Pine & 0.99 & 0.67 & 1.15 & 0.81 & 1.01 & 0.58 \\
Common & 1.08 & 0.88 & 1.01 & 0.79 & 0.94 & 1.15 \\
spruce & 1.08 & & & &
\end{tabular}

In 2018, the result of the aggregate index according to formula (4) for beech wood represents a price increase of $21 \%$ over the base period, which is the year 2015. Conversion to financial units represents an increase of 11.51 Eur.m ${ }^{3}$. The volume of beech wood, calculated according to formula (5), represents an increase of $73 \%$ in 2018 compared to the baseline period; which is the year 2015, which represents an increase of $2727.72 \mathrm{~m}^{3}$ (Table 4.).

For oak wood, the aggregate index value of formula (4) shows the price for oak wood in 2018 increased by $25 \%$ compared to the baseline period, which is the year 2015. Price increase is 13.73 Eur. $\mathrm{m}^{3}$. On the other hand, we can see a significant decrease of oak wood production by $68 \%$, after recalculation it is a decrease of $468.59 \mathrm{~m}^{3}$ compared to the base period of 2015 (Table 4.).

The calculation of the aggregate indices according to formulas (4) and (5) presents a price increase of $11 \%$ for pine wood in 2018, which represents a price reduction of Eur $3.91 \mathrm{~m}^{3}$ compared to the baseline period, which is the year 2015, the volume of harvested pinewood was reduced by $51 \%$, more precisely by a reduction of $89.15 \mathrm{~m}^{3}$ compared to the baseline period, which is the year 2015 (Table 4.).

The results of the aggregate indices according to formulas (4) and (5) show that the price of the Norway spruce tree increased only slightly by $1.3 \%$ in 2018, representing an increase of 0.64 Eur. $^{3}$ compared to the baseline period, which is the year 2015. The volume of harvested common spruce tree increased by $30 \%$ in 2018 , namely the increase represents $2375 \mathrm{~m}^{3}$ compared to the base period, which is the year 2015 (Table 4.). 


\section{Conclusions}

The logging was oriented mainly to the processing of calamities, namely after a wind calamity or bark beetle calamity. Subsequently, the sale of this calamity wood is connected to the processing of calamity wood. Positive aspect in terms of quality is afforestation with high-quality planting material, cultivation, protection and economically friendly logging. Planting of deciduous trees at the expense of conifers is also largely approached [13]. Consequently, the forest stands will be more stable and more resistant to natural influences.

Timber harvesting must be carried out with an understanding of natural principles in order to harvest and evaluate wood mass. The priority task in timber harvesting is to protect the forest and its hygiene, where, among other things, it is important to preserve cleanliness in the stands by timely removal of timber, or to remediate residues after logging, to prevent overgrowth. The problem is caused by logging waste, which can be solved by building a wood pellet line. In terms of society-wide needs, it can be stated that the construction of a wood pellet line will allow the processing of unused dead-mass, which remains in the forest e.g., from calamity logging or interventions to improve the condition and stability of forest stands.

\section{Acknowledgements}

This article was supported by the Slovak Cultural and Educational grant agency under the grants KEGA 017TUKE-4/2019 Creating a modular system of synergic cooperation for sustainable development and corporate social responsibility.

\section{References}

[1]. Pohjanmies, T., Eyvindson, K., \& Mönkkönen, M. (2019). Forest management optimization across spatial scales to reconcile economic and conservation objectives. PLOS ONE, 14(6), 1-16.

[2]. Bruchanik, R., Svancara, J., Zima, P., Zlocha, R. \& Kunca, A. (2017). Sustainable forest management. 3st ed. (in Slovak). Trvalo udržatel'né obhospodarovanie lesov. National Forest Centre.

[3]. Schober, A., Šimunović, N., Darabant, A., \& Stern, T. (2018). Identifying sustainable forest management research narratives: a text mining approach. Journal of Sustainable Forestry, 37(6), 537-554.

[4]. Kauppi, P. E., Sandström, V., \& Lipponen, A. (2018). Forest resources of nations in relation to human wellbeing. PLoS ONE, 13(5).

[5]. Sing, L., Ray, D., \& Watts, K. (2015). Ecosystem services and forest management. Research NoteForestry Commission, (020).

[6]. Kuzevic, S., Kuzevicova, Z., Bindzarova Gergelova, M., Herbrik, G. (2016). Environmental quality in the context of sustainable development in the Slovak republic. Quality and leading innovation, pp. 53-58.

[7]. Zimon, D., Gajewska, T., \& Malindzakova, M. (2018). Implementing the requirements of ISO 9001 and improvement logistics processes in SMES which operate in the textile industry. Autex Research Journal, 18(4).

[8]. Woodard, A. C., \& Milner, H. R. (2016). Sustainability of timber and wood in construction. In Sustainability of construction materials (pp. 129157). Woodhead Publishing.

[9]. Malindzakova, M., \& Puskas, D. (2018). Application of Environmental Quality Approaches to analyse Environmental Pollutions. Calitatea, 19(166), 107110.

[10]. Sloup, M., Lehnerova, L., Slodicak, M. \& Lehecka, J. (2019). Influence of educational interventions and development of pine stand. (in Czech). Lesnicka prace: časopis pro lesnicko-dřevařskou vědou a praxi, 98, 34-37.

[11]. Chlebikova, D. (2005). Economic statistics for managerial decision making, 1st ed. (in Slovak). Ekonomická štatistika pre manažérske rozhodovanie. The Faculty of Operation and Economics of Transport and Communications, Slovakia.

[12]. Trojan, J. (2019). Monitoring and measurement of sustainable forest management process. Diploma of Thesis. (in Slovak). Monitorovanie a meranie procesu udržatel'ného obhospodarovania lesov. Technical University of Kosice.

[13]. Martín-García, J., \& Diez, J. J. (2012). Sustainable forest management: An introduction and overview. Sustainable forest management-Current research, 3-16. 